\title{
Correction to: A crucial distinctive author contact information
}

\author{
John E. Culp ${ }^{1}$
}

Published online: 27 December 2021

○ The Author(s), under exclusive licence to The Associates for Philosophy of Religion 2021

\section{Correction to: International Journal for Philosophy of Religion https://doi.org/10.1007/s11153-021-09817-8}

In the original publication of the article, the name Karl Pfeifer in the texts and reference was incorrectly cited as Karl Pfeiffer. The name "Karl Pfeiffer" in the second and fifth paragraphs under the section "Proposals for the distinctiveness of panentheism" should be read as "Karl Pfeifer".

The correct reference is provided in this correction.

\section{Reference}

Pfeifer, K. (2020). Naïve Panentheism. In B. Godehard, P. G. Benedikt, \& J. Ludwig (Eds.), Panentheism and panpsychism: Philosophy of religion meets philosophy of mind (pp. 123-138). Mentis Verlag.

The original article can be found online at https://doi.org/10.1007/s11153-021-09817-8.

John E. Culp

jculp@apu.edu

1 Azusa Pacific University, Azusa, CA, USA 